\title{
Motherhood in Family Context - Comparing Professional Practices in Maternity and Child Health Care in Finland and Scotland
}

\author{
MARJO KURONEN, Ph.D. \\ Lecturer in Social Work \\ University of Jyväskylä, Finland \\ Department of Social Sciences and Philosophy
}

\begin{abstract}
The purpose of this article is to examine professional practices in maternity and child health care in two countries, Finland and Scotland, concentrating on how motherhood is located in family context, on how family is defined and worked with. Subthemes analysed are the role of fathers, 'family support' for mothers and the discussion over lone motherhood. The study was carried out through local case studies using ethnographic methods, mainly observation and interviews with health professionals. Results show that Finnish health professionals have adopted a family-oriented way of working emphasising the importance of pair relationships and shared parenthood, compared with their Scottish colleagues, who work in a more women-oriented way and emphasise the role of other women as social support for mothers. In conclusion the two different professional orientations are connected to wider social and cultural differences between the two countries.
\end{abstract}

Keywords: motherhood, family, maternity and child health care, Finland, Scotland

\section{Introduction}

In this article I discuss motherhood and its social conditions in two cultural and social contexts - in two countries, Finland and Scotland. As the 'point of entry' (Smith 1988) to the topic I use primary health services for mothers and young children, and professional practices of health professionals, mainly public health nurses in Finland and 
community midwives and health visitors in Scotland. Maternity and child health services are analysed as an institution defining and organising motherhood, women's daily lives and their responsibilities for their children's welfare and health.

Why I have chosen these two particular countries? First, comparative social policy research has shown that the welfare state systems in Scotland, as part of the UK, and in Finland differ remarkably and have different consequences for women as mothers (e.g. Lewis \& Ostner 1991; Anttonen \& Sipilä 1996; Millar \& Warman 1996). Several authors have also emphasised the ideological differences in the two countries. In the UK the state has adopted a policy emphasising the family's privacy and the parents' responsibilities, where intervention in family life and the child care practices of the parents is accepted mainly in problematic situations, whereas in Finland state intervention is seen to be more supportive, providing universal services for families with young children (e.g. Millar \& Warman 1996). In this respect, Finland and Scotland are different enough to provide interesting opportunities for comparison.

There are also enough similarities between the two countries in the provision of maternity and child health services in order to compare them in the first place. The recommended schedules of how often pregnant women and young children should be seen by the health professionals are quite similar, services are provided under public health services and are mainly free of charge for the service users, tests, screening and measurements taken are very much the same, a vast majority of babies in both countries are born in hospitals, and so on (see e.g. CRAG/SCOTMEG 1995; Hall 1991; Lastenneuvolaopas 1990; Screening and collaboration in maternity care 1996). However, in analysing the systems from the inside, the everyday work of health professionals and actual encounters between professionals and their clients, many differences can also be discovered.

The article is based on one of the themes of my Ph.D. thesis 'The social organisation of motherhood' (Kuronen 1999); I will ask how motherhood is located in family context in maternity and child health services. How 'family' is understood and worked with in the everyday practice of health professionals, and how their definitions of family are connected with wider social and cultural differences in the two countries. I will discuss the issue by analysing the role of fathers, 'family support' for mothers, and concern over lone motherhood in maternity and child health care in the two countries.

\section{Methodological approach and research methods}

Unlike most comparative, crossnational social studies, which have used a large-scale approach (see e.g. Hantrais \& Letablier 1996; Hantrais \& Mangen 1996; Millar \& Warman 1996), the methodological approach I adopted is local and particular using 
qualitative, ethnographic methods (I have discussed qualitative cross-cultural research more in depth elsewhere, see Kuronen 1999, 74-107; 2000). I wanted to get inside the process rather than look at the maternity and child health service systems from the outside, but I also wanted to be sensitive to cultural and social realities in a wider sense in order to understand what it means to be a mother in a particular social and cultural context.

The study was accomplished by undertaking local case studies in one city in Finland and in two cities and their surroundings in Scotland. Because the organisation of maternity and child health services is different in Finland and in Scotland, it was impossible to find identical settings in the two countries. Instead, the general criteria I used in choosing the settings was that I wanted to find the health services which pregnant women and parents of young children usually used. In data collection I used a very practical guideline offered by Hammersley and Atkinson (1983, 2): "The ethnographer participates, overtly or covertly, in people's daily lives for an extended period of time, watching what happens, listening to what is said, asking questions; in fact collecting whatever data are available to throw light on the issues with which he or she is concerned." However, the main part of the primary data consisted of observations of the work of health professionals and their interviews. In all the three areas the locations and individual professionals' participation was negotiated with medical or nursing managers.

The Finnish data was collected in one city I have named Tehtaala, one of the biggest cities in Finland, between 1990 and 1992, and some additional data in 1995-96. I spent altogether about three months in three different health centres mainly observing the work of public health nurses working with pregnant women and families with young children. I also interviewed seven public health nurses, three doctors and a psychologist.

The Scottish data was collected in 1995 in two cities and their surroundings, in two different Health Board areas. I call the Scottish cities Lochend and Strathdee. Lochend is quite a small town, whereas Strathdee is one of the biggest cities in Scotland. My fieldwork lasted about two months altogether, and I worked mainly with community midwives and health visitors. Community midwives were based in two hospital maternity units and health visitors in five health centres. I also followed parent education classes in two hospitals, organised by specialised midwives called parentcraft sisters. I interviewed eight health visitors, nine community midwives and two midwives specialised in parentcraft education.

The number of observed encounters between health professionals and clients was 265 in Tehtaala, 147 in Lochend and 122 in Strathdee. Data from my fieldwork was recorded in written field notes and tape-recorded and transcribed interviews. In order to locate and understand the local practice of health professionals in its organisational, cultural and social context, I collected additional material, such as national guidelines and policy documents concerning maternity and child health services (e.g. 
Neuvolatoiminnan kehittämistyöryhmän muistio 1984; Lastenneuvolaopas 1990; Provision of Maternity Services in Scotland.1994; Eating for health 1996; CRAG/SCOTMEG 1995; Screening and collaboration in maternity care 1996; Hermanson 1997). Additionally, I interviewed several nursing managers, consultants and researchers informally. Previous research on maternal and child health, but also on motherhood, families and family policies, and on the culture and history of the two societies has also been used as important secondary data.

The three local cases are not understood as 'representing' the maternity and child health services or health professionals in the entire countries in the same sense as in quantitative research. Rather, in ethnographic research local cases reveal what is culturally possible. Following the methodological guidelines of Canadian feminist sociologist Dorothy E. Smith (Smith 1988; 1990a; 1990b) I have used local practices of maternity and child health care as a 'point of entry', which provide access to more of a general understanding of the social organisation of motherhood at its different levels e.g. understanding of the ways in which family policies, different services and benefits or the lack of them, as well as social class and gender systems, historical and cultural tradition, customs and ways of thinking in a certain society organise the everyday world of motherhood, but also the work of health professionals.

\section{Family orientation and involvement of the father}

In the 1990s, both in the UK and in Finland, there has been a growing demand for shared parenthood and for a new, more active and participating father, a father who is present and caring, not only for his children but also for his partner. There has been a lot of discussion on 'new fatherhood' in the media, in social and psychological research, as well as among fathers themselves (Forsberg 1995; Isätoimikunnan mietintö 1999; Moss 1995). Still, unlike in Finland, in Scotland there was no legislation that would have officially recognised men as caring parents, there was no universal paternity, parental or care leave for fathers (Millar \& Warman 1996).

In both countries health professionals shared the view that men are different today than they were a few decades ago. They are not only more involved in pregnancy and childbirth but also in everyday child care. The health professionals I spoke to saw this as a positive development. There were, however, important differences in the ways in which fathers were recognised as parents and partners in maternity and child health services, as well as in the society as a whole.

In Finland fathers were expected to take an active role and share the experience right from the beginning of the pregnancy (see also Hakulinen 1998; Isät esiin 1998). Pregnancy and childbirth were seen for first-time parents as the time when a couple became 
a family. At this point their pair relationship, its emotional basis and quality, took on a special meaning.

We always inform the clients that the parenthood classes are meant for both, and that it would be good, if the father could be present at every session. Of course, some of the things are concretely only for the mother, but still. In that way, those things become more shared between the couple, and it is certainly easier for the father to share the experience, and also to support the mother. Then some sessions are really meant for both of them, like when we discuss becoming parents and pair relationships. We especially wish that they both come to that session, otherwise it is partly wasted, if the mother is the only one listening.

(Finnish midwife C)

The ideal seemed to be a couple that, through discussion and mutual agreement, changed their life according to the new situation, from an individualistic to a more family-centered lifestyle. A well-functioning, heterosexual, equal pair relationship and shared parenthood were very much the ideals expressed in maternity and child health centres in Tehtaala. It was an idealistic view, which ignored the possible problems, conflicts and gender inequalities in family life.

In the Finnish society women both as partners and professionals have taken an active role in producing and supporting men's parenthood (see also Forsberg 1995). In their encounters health professionals and their female clients were defining how men should be. Women were also expected to educate men in parenthood. Men should be encouraged and praised, they should be given opportunities to learn, and they should not be blamed for their mistakes. From time to time, as in the following extract from my field notes, professionals reminded women that they should give men opportunities to participate by not keeping the baby too much for themselves.

Postnatal visit in maternity centre. Woman has left the baby with her husband at home. She is in a hurry, because it is soon time to feed the baby... Midwife reminds her how important it is for her to get some time of her own, and tells her to leave the baby sometimes with the father. "He can do everything else except breast-feed". Woman says that her husband is taking care of the baby a lot.After the woman has left, the midwife is still wondering to me that she was so busy. According to her, some women just don't trust their partners in child care. She says that sometimes she would like to say quite firmly to some women during the postnatal home visits that she should let the father take care of the baby more. She has enough time to do her fair share after he has gone back to work. She continues that sometimes she can see very clearly that the father would like to do more, but his partner won't let him.

(Tehtaala field notes 85) 
It could be argued that in Finland it has became a woman's new responsibility not only to take care of her children, but also to build up a relationship between father and child by giving him opportunities to spend time with the child and encouraging him to participate in pregnancy, childbirth and child care. This educational task might even increase, instead of decrease, women's workload. The main issue is not that mothers need somebody to share child care and domestic work with, but to get men involved for their own and for the child's sake; to give men a chance to enjoy their children and parenthood (see also Huttunen 1996; Isätoimikunnan mietintö 1999). In maternity and child health services, as in the whole of Finnish society today, fatherhood is discussed a lot and in very positive terms.

\section{Men on the sidelines}

Scottish health professionals discussed fathers much less than their Finnish colleagues and they also made more negative remarks about men as fathers and as partners. It was quite common that fathers were not discussed at all in the encounters between health professionals and their female clients, or in the interviews I made. Professionals referred to their clients as 'women', 'girls', 'ladies' or 'mothers', not in gender-neutral terms, as 'families', as their Finnish colleagues often did. Discussions about men often occurred only because of my active questioning about the role of fathers in families and as clients for the health professionals. As one of the health visitors said in her interview, she hadn't really paid much attention to the issue before:

INT: You are very much working with mothers and children, but do you meet the fathers as well?

HV: Yes, some of the fathers. There is quite a high rate of unemployment, so I see quite a lot of the fathers in the houses. It is terrible because in some ways you are almost quite taken aback if the father is working in some areas, you really get quite sort of accepting of these facts that the fathers aren't working. Yes, we see quite a lot of them, some of them are beginning to come to clinics and things like that. Sometimes we see them at the antenatal clinics but not very often, not very often at all. Yes, beginning to see the fathers more, some of them are taking much more of an interest and taking part in their child.

INT: Are you trying to encourage them somehow to participate more, or do you find it important?

HV: I don't think I do. That's true, no I don't, no, I don't think I do. It is something that I maybe should because I think it is very important. I try when I go in, what I find is that when I go in on the first visit if the father is there, he seems to accept that this is really her role and he usually goes out of the way and usually I try to say things like, if I am going over the immunisation, like would you come in, this is something the two of you have to do. Very often I will say to the mother, if the father is not there 
before you sign this, would you like to discuss it with your partner, but that is true, quite often I don't really take into account the father, I should really. There maybe should be a way that we should try and incorporate them into the discussion more. I think it is very important.

(Scottish health visitor 7)

In the extract above it takes a while before the health visitor understands my 'familyoriented' question. First, she describes men's presence during her home visits in negative terms, as a consequence of the high unemployment rate in the area, not as men wanting to be active and participating fathers. Only later does she join the familyoriented discourse and begin to talk about the importance of the fathers' involvement, but at the same time admitting that she has not been very active in involving them. She and many of her colleagues referred to traditional cultural norms adopted by many men, that these are 'women's issues', but they had also not taken an active role in changing them.

In Scotland men have the same option to participate in parenthood classes and childbirth as in Finland. It has been suggested that in the UK women clients have been the primary motivators in this change, and the health service system has merely answered their demand (O'Brien and Jones 1995, 30). Health professionals in Tehtaala strongly emphasised that parenthood classes are meant for couples, whereas their Scottish colleagues expressed more the 'customer demand' for more couples' classes and men's involvement in childbirth than the active encouragement of men on their behalf. They saw that this should be an option, but there should be also other alternatives. They did not see men's participation in parenthood classes as entirely positive or even required, but mentioned that it might also prevent women from talking about private and intimate issues and make single pregnant women feel isolated and offended.

More and more men wish to be involved in the education and also involved in parenting. So the classes have increased quite dramatically in size although the content hasn't particularly changed, it has been refined to allow for men being in the group. For instance we don't now play with dolls, we don't play with dolls or breasts now when we are talking about breast-feeding, we just tend to talk about different aspects of the subject and a women-only breast-feeding workshop is held at another time for those women who are interested. We also don't show bras and sometimes don't talk about different aspects of the pelvic floor because men do get quite embarrassed, so you have got to watch the embarrassment factor, although they want the education they don't necessarily want the education in the public arena.

(Scottish midwife 10)

You often find that young mums will not go to the parentcraft education class that is full of married middle class women, they just feel intimidated, so they don't go. Teenagers, I think they need more health education and they also need to be able to 
talk to someone about their fears, and if they are in a group of women, middle class women, and they are worried about having no money, they are not going to highlight that. So I think we need to have a group just of young women, teenagers, so they can come along with their friends if they want to, rather than have to sit there and think, oh I don't have a partner and things like that.

(Scottish midwife 7)

I would argue that among Scottish health professionals the messages about men's role in family life were more mixed than in Finland. Ideally, men's participation in pregnancy, childbirth and child care was supported, but at the same time it was recognised that this was not the reality in many of the families. Men were seen either as unable, for example because of their long working hours, or unwilling to participate in family responsibilities. Traditional cultural values and gendered division of labour where men have had a marginal status in everyday family life were still strong (Wight 1993).

Men were often described as irresponsible, demanding services instead of helping women with the housework and child care, or sometimes even as rude and violent. The next long quotation is not typical but instead an extreme and exceptional example of how health professionals talked about women's male partners. However, it provides a 'summary' of all the negative comments about men and their family role:

Some of them (women - MK) are frightened of the men in their lives. ... And it is a strange thing to go into a house where you can witness the timorous behaviour of the woman, who appears quite subservient to the man and the man doesn't acknowledge your presence. It is a bit uncomfortable, so what you do at that point you just adjourn to a bedroom out of the way where you can relax because the women won't open up in front of the men. ... and there can be evidence of assault and there is not a great deal you can do because in a lot of these cases the women themselves accept that as a normal part of the relationship that they have with that person. I might not approve of it but there is very little I can do to influence it unless she specifically seeks my help, which they don't do. You come out of situations often thinking, oh dear, but your hands are tied. ... I would say a high percentage of cases families are happy but we do see very, very unhappy situations and we really aren't in a position to influence it and what you have got to be very careful of is that you don't actually create a problem for the girl.

(Scottish midwife 8)

This description of women living in oppressive or even in violent pair relationships is in a clear contrast to the ideals of the 'new father' and shared parenthood. The midwife in the extract above does not even call women's partners fathers but refers to them as 'that person' and 'the men in women's lives'. The awareness of the Scottish health professionals of the 'dark side' of family life, such as male violence, might be connected with the public discussion of the time, especially the Zero Tolerance campaign launched in Scotland in the mid-90s (Cavanagh \& Cree 1996). Although this was a 
marginal issue also among the Scottish professionals, their family discourse was quite different from their Finnish colleagues who operated with the positive image of the pair relationship, shared parenthood and gender relations in families.

\section{Family as a community of women}

Scottish professionals also discussed family and especially 'family support' for mothers with young children, but for them this supportive family was not the woman's male partner. Instead, family was often discussed as a community of women where the woman's own mother and other female relatives were seen as an important source of 'family support', which might mean emotional support, teaching of domestic skills, actual help in child care, financial support or even two generations living together. Everyday family life was very much seen as a women's issue.

During my data collection in Lochend and Strathdee grandmothers were also concretely more present than in Tehtaala, where they were occasionally discussed but hardly ever met. In Scotland, however, grandmothers came with their daughters to antenatal clinics, to parentcraft classes, brought children to baby clinics or they were met during the home visits.

Scotland is more of a class society than Finland, and that was seen also in the ways in which mothers, their family life and need for support were described by the health professionals. Middle class mothers were discussed very much with the same terms as the 'modern Finnish family', as a small nuclear family, whereas the working class family was seen as more traditional where close family ties among women still existed (see also Straw \& Elliott 1986). It was also the working class 'grannies' who were described as 'a bad influence' at the same time as they were praised as important support for their daughters (see also Blaxter and Paterson 1982; Mayall and Foster 1989; McIntosh 1992).

They have a lot of problems with feeding that you have to discuss. Also infant feeding practices have changed a lot in the last 20 years and a lot of these we girls tend to take their advice from their mother. Now when their mother had a baby it was quite normal that you started a baby on solids at about 6 weeks or even earlier for some of them, so it is quite important that we get that message across to them quite early, the reason why we don't think that is a good idea nowadays. Otherwise granny will suggest and the girls will go with it.

(Scottish health visitor 6)

On the other hand, health professionals were worried that in the modern society close family ties between women were loosening up. Even in middle class family life, male 
partners were not seen to have replaced female relatives, and middle class mothers were often described as isolated because of their lack of family support.

I think because it (the area-MK) is quite rural and quite middle class and a lot of women have moved away from their families so they don't have the back-up of the extended family. So they tend to be isolated in a way so they seem to depend more on the midwife for support. In comparison to the inner cities where maybe the families are quite close together, they have got their mum down the road or their granny down the road, they seem to get a lot more support from the family. A lot of the women in our area don't, they are just by themselves and their husband.

(Scottish midwife 7)

Professional advice was sometimes seen as an alternative to missing family support. Not only in Scotland but also in Finland, the disappearance of traditional family relations has been mentioned as a reason for the increased need for professional support and advice for new parents (Vehviläinen-Julkunen 1990, 2). However, in Finland parents are expected to help and support each other, whereas in Scotland support for mothers is primarily seen as coming from other women, either from family members or from health professionals.

\section{Lone mothers}

In both countries, a remarkable number of families with children are headed by a lone mother, 20\% in Scotland and 16.5\% in Finland (One Parent Families Scotland 1998; Tilastokeskus 1998). Still, the social situation of lone mothers and the public debate around lone motherhood is very different in the two countries, as was the recognition of lone mothers as a specific client group by the health professionals.

According to Jane Lewis, in Britain from the 1980s onwards one of the most heated debates in relation to family life has been about lone-parent families together with the responsibilities of the 'missing fathers' (Lewis 1993). Lone-parent families headed by women, especially never-married young single mothers, are seen in the public debate as a threat to traditional family values and as a financial problem for the state. The political and public climate in the 1990s made single motherhood first and foremost a moral issue ignoring the social reasons of poverty among lone mothers. (Mann and Roseneil 1994; Millar 1994; Wasoff \& Dey 2000, 32-40. Terms 'lone mother' and 'single mother' can be used as synonyms, but I make here a distinction between the two. I use 'lone mother' as a more general and neutral term whereas with 'single mother' I refer to never-married mother, but also to a specific British discussion.)

In Finland there has been less public debate on lone motherhood and not such a strong connection has been made between lone motherhood, social class and social problems 
as is the case in the UK (see also May 1999). Also the economic situation of loneparent families has been seen as fairly good in international comparison, because lone mothers maintain themselves and their children with their own earnings, working full time, and the welfare state has made it possible for them to combine motherhood and paid work (Forssén 1997).

This is not to imply that lone-parent families are not seen as a problem at all in Finland. 'Broken homes' and growing up in a lone-parent family are still often used as an easy explanation for children's social and psychological problems. Still, it could be argued that, at least since the late $1980 \mathrm{~s}$, rather than lone mothers being viewed as a special problem, they have been seen as one example of the increasing diversity of family forms. There has been a public debate for and against the traditional nuclear family (see Forsberg et al. 1991 for more about this debate). There are supporters of the nuclear family who have argued that other family forms, such as lone parenthood and cohabitation, have been made too attractive compared to marriage. But there has also been a growing demand that different family forms, married and cohabiting couples, reconstituted families and most recently lesbian and gay couples, should be treated equally, for example in legislation (Perheet ja laki 1992; Kaskisaari 1997; Jaakkola \& Säntti 2000).

Correspondingly, among Finnish health professionals there was more discussion about changing family forms and relations than about lone motherhood as such. Single pregnant women were mentioned as rare exceptions. There was also some confusion about who should be defined as a single mother, where the line should be drawn, because for the health professionals being unmarried, or even living apart, does not necessarily mean being a single mother.

At the moment I don't have any single mothers. Except one, how should I put this, who is partly alone, because her partner lives abroad. Of course, from time to time, there are mothers whose relationship is somehow unstable, or the partner is a foreigner and lives abroad, and can't get a permit to stay here permanently. These kinds of cases I have from time to time. It brings its own problems to the pregnancy. But, really, for a long time I haven't had any mothers who have no support at all from the child's father, who are all on their own.

(Finnish midwife E)

Instead of talking about single mothers who are alone right from the beginning, Finnish health professionals more often discussed divorced or separated parents and their new families. Changing family forms were seen as causing emotional problems for children and it was emphasised that children have the right to maintain a relationship with their parents. Still, the problems in maintaining these relationships were also recognised. What was seen as important was continuity, both the continuity of biological family relations, and the continuity of the mother's new relationship - the father's new relationship was rarely mentioned as a problem. 
INT: Are there any special questions that come up with them (lone-parent families $M K)$ here, or that you see as important to discuss with them?

$\mathrm{HN}$ : At least I always say, from the child's point of view, that every child has the right to have a father and a mother. That's what I have said. It is the most important basic principle I want to emphasise. And I ask if the child has been meeting her parent, whether it is the mother or the father that is missing from the family, whether meetings are arranged. And also that the child has somebody else as a father figure or a mother figure. Quite often this kind of a father figure is missing these days.

(Finnish health nurse J)

INT: You already mentioned, that nowadays there are more stepfamilies? What are the issues that you have come across in your work concerning stepfamilies, or that your clients discuss with you?

MW: It could be that these things are not discussed at all, but if I feel that I can ask... I have quite directly asked, for example, how often they meet the children who are not living in the family. And how it works out if the distances are long. Just at the moment I have a family where the father's children from his ex-marriage live quite far away. This mother says that it is so exhausting, she is not always willing to go, and this causes conflicts between them. ... I think these are quite big problems. If you think, like in this family, that there is one child from the mother's ex-marriage who lives with them. The mother drives him every other weekend to see his father, who lives far away from here, and it is hard especially now when there is this new baby. Then there are the father's children, three of them, who come to meet their father, often one at a time, but sometimes two of them might come at the same time. ...I think it helps when we talk about these things, although there is really no concrete help to offer, except maybe to suggest that these meetings could be arranged differently for a while now when there is this new baby.

(Finnish midwife E)

Missing fathers or 'father figures' and children's relationship with them seemed to be the main concern for the health professionals in Tehtaala, not the everyday life or coping of lone mothers. Hannele Forsberg (1995), who has studied the ways in which fatherhood is discussed in encounters between social workers and their clients, has also noted that divorced women were encouraged to maintain the relationship between father and children, even if the relationship between the former partners had been problematic, or even violent. Shared parenting and joint custody is also the 'spirit' of the current legislation (Kurki-Suonio 1999).

In Scotland, there were no discussions about fathers living apart from their children, or about the need of children to keep in touch with them. Instead of separated parents and reconstituted families, single mothers were discussed much more often. Single motherhood was often connected with teenage pregnancies and a working class background. 
Descriptions about single motherhood were very much problem-oriented, but health professionals emphasised that not all of them have problems in parenting. It is also interesting that single motherhood and the problems single mothers were seen to have were connected more with very practical issues in the organisation and management of their daily lives rather than with the missing pair relationship and the missing father.

INT: Do you think they (single mothers - MK) need more from you than the others? MW: It depends on the individual. Some of these single mums are very confident and they have brought up their younger brothers and sisters more or less because their mum has maybe gone out to work so they know what bringing up children is all about. I know it is different having your own but they seem to cope and they don't really want to come along to parentcraft education because they know how to make up bottles, they know how to bathe the baby, they know how to change a nappy. It is all done on an individual basis really and how we think they are going to cope by the state of the house and things like that.

(Scottish midwife 5)

INT: You said that you have quite a lot of single mothers, do you find that they are a special group who need more of your time?

HV: Some of them, yes, do need a lot of reassurance, a lot of guidance and a lot of support. Quite a few of the single mums are very caring, very good providers and they manage very well. Some of them are just able to cope better than others.

(Scottish health visitor 4)

The way in which Scottish health professionals talked about single mothers was sometimes quite judgmental and problem-oriented, but it also differed from the political debate and public 'moral panic' of the 1990s over single motherhood (Mann \& Roseneil 1994; Lewis 1997). Their competence as mothers was assessed according to their practical skills and 'coping' in their daily lives. Health professionals were also quite sensitive and understanding of the everyday life and problems of single mothers. In Finland, instead, a lasting, stable pair relationship was much more likely to be seen as an essential part of parenting and family life, and the whole issue of lone mothers was very much ignored.

\section{Conclusions}

In conclusion, I am arguing that motherhood is located in family context very differently in the maternity and child health services in the two countries. In Scotland the health professionals studied were working in a women-oriented way, with and for women, compared with their Finnish colleagues who had adopted a strong (nuclear) family orientation in their daily work. Differences in professional orientation can be connected 
and are in accordance with the family policies and gender systems in the two societies. Family and parenthood are understood differently, not only in maternity and child health care, but also in the societies as a whole. At the end, I will draw connections between the local practices of maternity and child health services and the social organisation of motherhood in the two societies.

First, there is a connection between the family orientation of maternity and child health services and the ideal of gender equality of the Finnish society. One of the main principles of the Finnish family policy and the welfare state has been to support gender equality in families as well as in the society as a whole. Gender equality really became an issue in Finland in the radical 1960s. According to Raija Julkunen (1994; see also Jallinoja 1983) the gender equality organisation 'Yhdistys 9' (Association 9) was an important representative of the new radical, modern ideals. The main objective was women's emancipation, but also the changing role of men. There was, for example, a demand for paternity leave, which was achieved in the late 1970s. Women's equal participation in the labour market was understood as one of the cornerstones of women's emancipation, and a working mother was the ideal woman of the time - as she still very much is. What was required to gain the target was family policy measures, especially public day care for children, but also participation of men in child care and housework. So, since the 1960s Finnish women have in many ways supported a more active family role for men, as they now do in maternity and child health care.

What has been characteristic of the Finnish equality policy and women's movement is that they have been based on the ideal of similarity rather than difference between women and men. Finnish women, unlike radical feminists elsewhere, have also worked both with and within the state, and with men. In the 1960 s problems in the position of women were understood as a conflict between the traditional and modern society rather than as a conflict between women and men. It was assumed that women and men should work together to make society more equal. Man was seen as a norm, which women should attain. The ideal of similarity has also influenced language use, making it to more gender neutral. In Finland, instead of women, we often talk about persons, parents, spouses and families (Julkunen 1994; see also Honkanen 1993). The same gender neutrality in language, talking about parenthood and family rather than motherhood, can be found in maternity and child health care.

In the UK, the relationship between women, family and the state is quite different. What has been criticised by many feminists is the traditional family model, which is embedded in the British society and its welfare state system (e.g. Lewis 1992; Millar 1994). This male breadwinner and female carer -model is based on separate spheres and responsibilities for women and men in the family and in the society as a whole. The distinctness of male and female spheres was also present in the work of Scottish health professionals: pregnancy, childbirth and child care were seen as women's issues where men had only a marginal role. As mentioned earlier, in the UK, there is also no legisla- 
tion that would recognise men as caring parents, even if there has been a lot of discussion about it recently and changes in legislation are probably coming in the near future (Wasoff and Dey 2000, 124-125). Health professionals accepted the primary role of women and the marginal role of men referring to the cultural traditions or the demands of working life, rather than actively tried to change the situation.

The women-oriented way of working by the Scottish health professionals is also in accordance with feminist discussion in the UK, which has emphasised the difference between women and men, and women's oppression in personal life, in such issues as reproduction, sexuality and male violence. Several women's groups, for example the Association for Improvements in the Maternity Services (AIMS) and National Childbirth Trust (NCT) along with many feminist researchers (e.g. Graham 1993; Oakley 1992) have also emphasised maternal and child health and welfare as women's issues, rather than a 'family issue', where women's needs should be recognised and met.

To some extent, Scottish health professionals seemed to have a feminist orientation in their work even if the word 'feminism' was never mentioned. At the same way as in feminist social work (e.g. Dominelli and McLeod 1989; Phillipson 1992), health professionals saw themselves working with and for women, paying attention to the problems women meet in their everyday life, and sometimes acting as advocates of women, for example in relation to male doctors. They also emphasised the importance of women's supportive networks rather than the male partner as a companion and a main source of help and support.

In Finland, instead, it seems to me that in the 1990s, fatherhood has become a bigger issue than motherhood in the public debate, professional practice, as well as in academic research, even in feminist research (see also Vuori 1999). I agree that parenthood should be more equally shared between women and men, and shared parenthood should be promoted in different ways in society. But the women-centered orientation of the Scottish professionals demonstrates the limitations and disadvantages of the familycentered orientation, which might ignore issues and problems that are specific to women and also hide the 'dark side' of family life.

\section{References}

Anttonen, Anneli and Jorma Sipilä. 1996. European Social Care Services: Is It Possible to Identify Models? Journal of European Social Policy 6(2):87-100.

Blaxter, Mildred and Elizabeth Paterson. 1982. Mothers and daughters. A three-generational study of health attitudes and behaviour. London: Heinemann Educational Books.

Cavanagh, Kate and Viviene E. Cree (eds.). 1996. Working with men. Feminism and social work. London and New York: Routledge.

CRAG/SCOTMEG. 1995. Antenatal care. The Scottish Office. National Health Service in Scotland. 
Dominelli, Lena and Eileen McLeod. 1989. Feminist Social Work. Basingstoke and London: Macmillan.

Eating for Health. 1996. A diet action plan for Scotland. The Scottish Office Department of Health.

Forsberg, Hannele. 1995. Sosiaalitoimiston isä: kaivattu, toivoton ja uhkaava. (Missed, hopeless, threatening - Constructing fatherhood in social work practices) In: Naiset $y k s i-$ tyisen ja julkisen rajalla, edited by Leena Eräsaari, Raija Julkunen and Harriet Silius. Tampere: Vastapaino.

Forsberg, Hannele, Marjo Kuronen, Tarja Pösö and Aino Ritala-Koskinen. 1991. Kun perhe hajoaa ja on kuitenkin kaikkialla (When the family breaks up but is all around you). Sosiaalipolitiikka 1991, pp. 37-49. Vammala: Sosiaalipoliittinen yhdistys.

Forssén, Katja. 1997. Yksinhuoltajat ovat lama-ajan taloudellisia häviäjiä (Lone parents are the economic losers of the recession). Sosiaaliturva 4:8-10.

Graham, Hilary. 1993. Hardship and Health in Women's Lives. Hemel Hempstead Harvester Wheatsheaf.

Hakulinen, Tuovi. 1998. The family dynamics of childbearing and childrearing families, related family demands and support received from child health clinics. Acta Universitatis Tamperensis; 585. Tampere: Tampereen yliopisto.

Hall, David M.B. (editor). 1991. Health for all children: a programme for child health surveillance. The Report of the Joint Working Party on Child Health Surveillance. Oxford: Oxford University Press.

Hammersley, Martyn and Paul Atkinson. 1983. Ethnography. Principles in Practice. London: Routledge.

Hantrais, Linda and Marie-Thérese Letablier. 1996. Families and family policies in Europe. London and New York: Longman.

Hantrais, Linda and Sten Mangen (eds.). 1996. Cross-national research methods in the social sciences. London and New York: Pinter.

Hermanson, Elina. 1997. Lapset perusterveydenhuollossa: Katsaus lastenneuvolan kehitykseen, visio tulevaan (Children in primary health care). Aiheita 24/1997. Helsinki: Stakes.

Honkanen, Katriina. 1993. Vilken kvinna? Om uppfatningar om kvinnor inom kvinnorörelsen och feministisk teori (What woman? Understandings of women in the women's movement and feminist theory). Naistutkimus - Kvinnoforskning 6(3):50-58.

Huttunen, Jouko. 1996. Full-time fathers and their parental leave experiences. In: Men 's family relations, edited by Ulla Björnberg and Anna-Karin Kollind. Stockholm: Almqvist \& Wiksell International.

Isät esiin (See the fathers). 1998. Neuvola-lehti 1:18.

Isätoimikunnan mietintö (Committee on fatherhood report). 1999. Komiteamietintö 1999:1. Helsinki: Sosiaali- ja terveysministeriö.

Jaakkola, Risto and Riitta Säntti. 2000. Uusperheitten lapset ja vanhemmat (Parental responsibility for children in reconstituted families) Publications no. 174. Helsinki: National Research Institute of Legal Policy.

Jallinoja, Riitta. 1983. Suomalaisen naisasialiikkeen taistelukaudet (Ages of battle of the Finnish women's movement). Juva: WSOY.

Julkunen, Raija. 1994. Suomalainen sukupuolimalli - 1960-luku käänteenä. (The Finnish gender model - 1960s as a turning point) In: Naisten hyvinvointivaltio, edited by Anneli Anttonen, Lea Henriksson and Ritva Nätkin. Tampere: Vastapaino.

Kaskisaari Marja. 1997. Homoparisuhdekeskustelu - diskurssi ja performatiivi (Debate on homosexual relationships - discourse and performance. In: Ruumiin siteet. Tekstejä eroista, järjestyksistä ja sukupuolesta, edited by Eeva Jokinen. Tampere:Vastapaino. 
Kurki-Suonio, Kirsti. 1999. Äidin hoivasta yhteishuoltoon - lapsen edun muuttuvat oikeudelliset tulkinnat (From maternal care to joint custody: The changing legal interpretations of the best interest of the child). Suomalaisen lakimiesyhdistyksen julkaisuja A-sarja N:o 222. Helsinki: Suomen lakimiesyhdistys.

Kuronen, Marjo. 1999. The Social Organisation of Motherhood. Advice giving in maternity and child health care in Scotland and Finland. Unpublished Ph.D. thesis. University of Stirling. Department of Applied Social Science.

- 2000. Ethnographic approach in cross-cultural research - Experiences and examples of a research project. Paper presented in the meeting of the Nordic research network "Language, interaction and social care in the Nordic welfare systems" 2-5 August 2000. Åland islands. (unpublished)

Lastenneuvolaopas (Guidelines for child health centres). 1990. Lääkintöhallituksen opassarja no 7. Helsinki: Valtion painatuskeskus.

Lewis, Jane. 1992. Gender and the development of welfare regimes. Journal of European Social Policy 2(3): 159-174.

-. 1997. Lone mothers: the British case. In: Lone mothers in European welfare regimes, edited by Jane Lewis, pp. 50-75. London. Jessica Kingsley Publishers.

Lewis, Jane and Ilona Ostner. 1991. Gender and evolution of European social policies. CES workshop on Emergent Supranational Social Policy: The EC's Social Dimension in Comparative Perspective. Nov. 15-17th 1991. Centre for European Studies. Harvard University.

Mann, Kirk and Sasha Roseneil. 1994. 'Some mothers do 'ave 'em: backlash and the gender politics of the underclass debate. Journal of Gender Studies 3(3):317-331.

May, Vanessa. 1999. Work and financial survival in the life stories of Finnish lone mothers: Complicating the existing research narrative on the financial aspects of lone motherhood. Meddelanden från ekonomisk-statsvetenskapliga fakulteten vid Åbo Akademi. Sociologiska institutionen Ser A:504. Åbo: Åbo Akademi.

Mayall, Berry and Marie-Claude Foster. 1989. Child Health Care. Living with children, working for children. Oxford: Heinemann.

McIntosh, James. 1992. The perception and use of child health clinics in a sample of working class families. Child: care, health and development 18(3):133-150.

Millar, Jane. 1994. State, family and personal responsibility: The changing balance for lone mothers in the United Kingdom. Feminist Review 48: 24-39.

Millar, Jane and Andrea Warman. 1996. Family obligations in Europe: the family, the state and social policy. York: Joseph Rowntree Foundation.

Moss, Peter (ed.). 1995. Father figures. Fathers in the families of the 1990s. Edinburgh: HMSO.

Neuvolatoiminnan kehittämistyöryhmän muistio. 1984. (Committee report on developing maternity and child health services) Työryhmämuistio 1984:28. Helsinki: Sosiaali- ja terveysministeriö.

Oakley, Ann. 1992. Social Support and Motherhood. The Natural History of a Research Project. Oxford \& Cambridge: Blackwell.

O'Brien Margaret and Deborah Jones. 1995. Young people's attitudes to fatherhood. In: Father figures. Fathers in the families of the 1990s, edited by Peter Moss. Edinburgh: HMSO.

Perheet ja laki (Families and the law). 1992. Perhetoimikunnan mietintö. Komiteamietintö 1992:12.

Phillipson, Julia. 1992. Practising equality. Women, men and social work. Farnborough: CCETSW and Hants.

Provision of Maternity Services in Scotland. 1994. A Policy Review. The Scottish Office. Home and Health Department. 
Screening and collaboration in maternity care. 1996. Helsinki: National research and development centre for welfare and health.

Smith, Dorothy E. 1988. The everyday world as problematic. A feminist sociology. Milton Keynes and Oxford: Open University Press.

Smith, Dorothy E. 1990a. The conceptual practices of power: A feminist sociology of knowledge. Toronto: University of Toronto Press.

Smith, Dorothy E. 1990b. Texts, facts, and femininity. Exploring the relations of ruling. London and New York: Routledge.

Straw, Pat and Brian Elliott. 1986. Hidden rhythms: hidden powers? Women and time in working-class culture. Life Stories (2):34-47.

Vehviläinen-Julkunen, Katri.1990. Nursing in child health care. Maintaining awareness of the child's development and care. Kuopion yliopiston julkaisuja. Yhteiskuntatieteet. Alkuperäistutkimukset 3/1990. Kuopio: Kuopion yliopisto.

Vuori, Jaana. 1999. Äideistä on moneksi (The plurality of motherhood). NaistutkimusKvinnoforskning 7(2):170-85.

Wasoff, Fran and Ian Dey. 2000. Family policy. Eastbourne: The Gildredge Press.

Wight, Daniel. 1993. Workers Not Wasters. Masculine Respectability, Consumption \& Employment in Central Scotland. Edinburgh: Edinburgh University Press. 